\title{
E-xperience Erasmus: Online Journaling as a Tool to Enhance Students' Learning Experience of their Study Visit Abroad
}

Odette Gabaudan

Technological University Dublin, odette.gabaudan@tudublin.ie

Follow this and additional works at: https://arrow.tudublin.ie/aaschlancon

Part of the Bilingual, Multilingual, and Multicultural Education Commons, Curriculum and Instruction Commons, and the Educational Assessment, Evaluation, and Research Commons

\section{Recommended Citation}

Gabaudan, O. (2013). E-xperience Erasmus: Online Journaling as a Tool to Enhance Students' Learning Experience of their Study Visit Abroad. In 20 Years of EUROCALL: Learning from the Past, Looking to the Future: 2013 EUROCALL Conference, Évora, Portugal, Proceedings, 93-97. ISBN: 978-1-908416-13-1

This Conference Paper is brought to you for free and open access by the Languages at ARROW@TU Dublin. It has been accepted for inclusion in Conference Papers by an authorized administrator of ARROW@TU Dublin. For more information, please contact arrow.admin@tudublin.ie, aisling.coyne@tudublin.ie, gerard.connolly@tudublin.ie. 


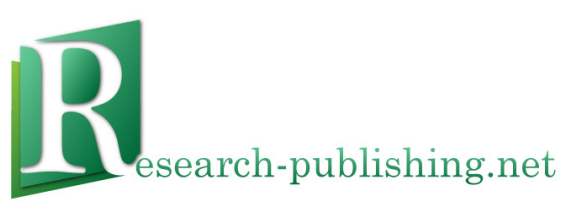

Published by Research-publishing.net

Dublin, Ireland; Voillans, France

info@research-publishing.net

(C) 2013 by Research-publishing.net

Research-publishing.net is a not-for-profit association

20 Years of EUROCALL: Learning from the Past, Looking to the Future.

2013 EUROCALL Conference, Évora, Portugal, Proceedings

Edited by Linda Bradley and Sylvie Thouësny

The moral right of the authors has been asserted

All articles in this book are licensed under a Creative Commons Attribution-Noncommercial-No Derivative Works 3.0 Unported License. You are free to share, copy, distribute and transmit the work under the following conditions:

- Attribution: You must attribute the work in the manner specified by the publisher.

- Noncommercial: You may not use this work for commercial purposes.

- No Derivative Works: You may not alter, transform, or build upon this work.

Research-publishing.net has no responsibility for the persistence or accuracy of URLs for external or thirdparty Internet websites referred to in this publication, and does not guarantee that any content on such websites is, or will remain, accurate or appropriate. Moreover, Research-publishing.net does not take any responsibility for the content of the pages written by the authors of this book. The authors have recognised that the work described was not published before (except in the form of an abstract or as part of a published lecture, or thesis), or that it is not under consideration for publication elsewhere. While the advice and information in this book are believed to be true and accurate on the date of its going to press, neither the authors, the editors, nor the publisher can accept any legal responsibility for any errors or omissions that may be made. The publisher makes no warranty, expressed or implied, with respect to the material contained herein.

Trademark notice: product or corporate names may be trademarks or registered trademarks, and are used only for identification and explanation without intent to infringe.

Copyrighted material: every effort has been made by the editors to trace copyright holders and to obtain their permission for the use of copyrighted material in this book. In the event of errors or omissions, please notify the publisher of any corrections that will need to be incorporated in future editions of this book.

Typeset by Research-publishing.net

Cover design: (C) Raphaël Savina (raphael@savina.net)

Photos: (c) Fany Savina (fany.savina@gmail.com)

Fonts used are licensed under a SIL Open Font License

ISBN13: 978-1-908416-12-4 (Paperback, Print on Demand, Lulu.com)

ISBN13: 978-1-908416-13-1 (Ebook, PDF file, Open Access, Research-publishing.net)

ISBN13: 978-1-908416-14-8 (Ebook, Kindle Edition, Amazon Media EU S.à r.1.)

ISBN13: 978-1-908416-15-5 (Ebook, ePUB file, Open Access, Research-publishing.net)

Legal deposit, Ireland: The National Library of Ireland, The Library of Trinity College, The Library of the University of Limerick, The Library of Dublin City University, The Library of NUI Cork, The Library of NUI Maynooth, The Library of University College Dublin, The Library of NUI Galway.

Legal deposit, United Kingdom: The British Library.

British Library Cataloguing-in-Publication Data.

A cataloguing record for this book is available from the British Library.

Legal deposit, France: Bibliothèque Nationale de France - Dépôt légal: novembre 2013. 


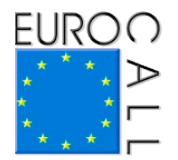

\title{
E-xperience Erasmus: Online Journaling as a Tool to Enhance Students' Learning Experience of their Study Visit Abroad
}

\author{
Odette Gabaudan ${ }^{1}$
}

\begin{abstract}
Students on the BA International Business and Languages who spend a full academic year on a study visit abroad experience many new challenges such as a different culture, a new university, different academic practices, a foreign language, etc. The assessment methods for the year include the results of the modules taken in the partner universities, a language examination and the submission of a country notebook. This research is a pilot study that explores how the maintenance of an online journal via a blog/e-portfolio structure can support students in their new learning experiences, alert the home coordinator to any potential difficulty before it escalates, provide them with regular online feedback on their progress and enhance their final reflective paper submission. The cohort of students is small and limited to those who are currently in France, spread across five different locations. The research is framed within an interpretivist paradigm using case-study as a research design. Data is gathered through documentary evidence, field observations, questionnaires and interviews. The project's results are of interest to Erasmus coordinators and educational institutions whose programmes include a study visit or even a placement component. The research brings insights on how reflective thinking can augment students' learning by practicing regular online reflective writing. Rubrics are used as a powerful tool for online feedback and for the continuous formation of students' learning. The advantages and challenges of using an enhanced blog structure for the maintenance of an online journal are also reviewed.
\end{abstract}

Keywords: online journaling, reflective writing, language learning, study visit, Erasmus.

1. Dublin Institute of Technology, Dublin, Ireland; odette.gabaudan@dit.ie

How to cite this article: Gabaudan, O. (2013). E-xperience Erasmus: Online Journaling as a Tool to Enhance Students' Learning Experience of their Study Visit Abroad. In L. Bradley \& S. Thouësny (Eds.), 20 Years of EUROCALL: Learning from the Past, Looking to the Future. Proceedings of the 2013 EUROCALL Conference, Evora, Portugal (pp. 93-97). Dublin/Voillans: (C) Research-publishing.net. 


\section{Introduction}

Undergraduate students who spend a full academic year on an Erasmus study visit experience many new challenges. They have to adapt to a different culture, a new university and different academic practices. They need to make new friends and they are often away from home for a period of time longer than a holiday. For many who go on an Erasmus study visit, one of the primary objectives is to become confident and comfortable with the foreign language that they have chosen as part of their course of study.

This paper is based on a pilot initiative with students who study French as their major language on the BA (Hons) International Business and Languages in the Dublin Institute of Technology (DIT) in Ireland. During their four-year programme, students are required to spend their third year on a study visit abroad. Students' performance over the course of the year is evaluated by a mix of assessment methods including results of modules taken in partner universities, a language examination upon their return to DIT and the submission of a country notebook. This research explored how the maintenance of an online journal, using a blog or e-portfolio format, can support students in their new learning experiences, foster regular communication with the home tutor, provide them with regular online feedback on their progress, enhance their final reflective paper submission, and facilitate peer learning and support.

The focus of this paper is on online journaling as a vehicle for supporting students' learning in particular in terms of reflective writing and language development.

\section{Method}

The research is framed within a phenomenological paradigm as it aims to gain insights into the contextualised processes, the subjective views and the multiple realities of the students who engage with their experience of the year abroad (Merriam, 2001). The enquiry seeks to explore not only the students' behaviour as seen from their own standpoint but also the researcher's interactions with the participants and overarching pedagogical objectives.

As a direct participant, the researcher brought her own pedagogical values and bias to the research. The methods now described are framed within an educational case study design. They were chosen in order to describe and reveal the meaning of the investigated social phenomena rather than to report on its frequency (Van Maanen, 1983, cited in Hussey \& Hussey, 1997). Methods included documentary 
evidence (students' blog entries, researcher's field notes), observations (tracking of students' interactions with journal entries in terms of content, length, depth of analysis, media and language used), questionnaires (sent by email) and semistructured interviews with a sample of students.

\section{Discussion}

\subsection{Implementation}

During their second year, students set up their blog on wordpress.com, a free blogging tool that incorporates many of the features recommended in the literature such as being user friendly, promoting a sense of ownership, providing options for customisation and sharing with others (Garrett, 2011; Jafari, Mcgee, \& Carmean, 2006; Plaisir, Hachey, \& Theilheimer, 2011). The coordinator also set up her blog as a means of communicating with the group on pedagogical matters linked to the online journal.

Activities designed to develop students' reflective writing skills and practice with the foreign language were posted on the coordinator's blog on a monthly basis. Feedback on students' reflective writing and language competence was also provided on a monthly basis, both individually and to the group. Individual written commentaries were posted on each student's blog. In addition, the researcher designed a rubric which she annotated and emailed to individual students on completion of their monthly activities.

\subsection{Reflective writing}

Each of the monthly activities focused on one of the learning outcomes set out in the programme documentation for the year abroad. One of the key aims for the monthly activities was to support students in their engagement with reflective writing. A reflective activity consists in making sense of one's world by standing back from the immediacy of reality, seeing reality from different perspectives, questioning assumptions and practices, analysing successes and failures, and reflecting on how to use previous experience for future action (Dalal, Hakel, Sliter, \& Kirdendall, 2012; Moon, 2006).

As a means of guiding critical reflection, the researcher developed a rubric that included a number of criteria and four corresponding levels of performance. This rubric served as a formative assessment tool, helping students to frame their performance on each criterion within an overarching frame of different levels. 


\subsection{Learning of French}

Reflective writing was a new activity for most students and none had previously engaged in reflective activity through French. Students always find the initial immersion into the French language and culture a challenge. They can feel overwhelmed by their new environment. In an attempt to reduce this sense of overload, students were initially given the option to post their entries in English. All three interviewees report having done their initial postings, at least partly, in English but, in hindsight, feel that it could have been of benefit to complete them in French from the outset. In spite of the added language difficulty and therefore time and effort required, "it is a French blog so it makes sense to write in French" as reported by one of the interviewees.

Students whose competency in the foreign language is lower find they have to try harder while students with a higher level of French enjoy the opportunity to express their thoughts in writing through French as this often remains the greatest challenge on their journey towards language acquisition. On completion of the reflective activity, a number of students report experiencing a sense of achievement. Such comments show that providing students with opportunities to build their confidence and develop their written fluency is as important as fostering reflective writing skills. Posting reflective activities in French is much appreciated by all students who engaged with the online journal as in many instances they do not get regular academic practice in composing in French nor do they get feedback on their actual language competence. Consequently, students particularly value the combination of practice and feedback.

\section{Conclusions}

While two thirds of the students fully engaged with the online journal, another third did not. The same third did not complete the questionnaire or participate in the interviews. It is the researcher's intention to investigate the underlying reasons for this lack of engagement with an initiative that has otherwise been considered very positive by all other participants.

Indeed, interviewees are unambiguous about the value of maintaining an online journal. They also unequivocally appreciate the tutor's feedback and feel that knowing the tutor will read their entries stimulates them to complete the tasks set out for them. Encouraging students and providing them with opportunities to develop a sense of achievement are key factors in sustaining students' engagement after their initial attempts at online journaling and reflective writing through French. 
Reflective writing is a challenging activity for students and it requires considerable time and skill for tutors to provide useful and meaningful feedback. To that effect, rubrics are valuable tools that give students clear indications on areas to improve, particularly when face-to-face communication is not possible as is the case when students are abroad for a lengthy period of time.

The main constraint to online journaling as a form of pedagogical support is the time required to adequately guide students in their reflective writing and in their language development. Tutors should be given adequate allowances so they can invest the necessary time and effort, particularly for cohorts of students that are larger or that require a higher level of guidance and encouragement.

\section{References}

Dalal, D. K., Hakel, M. D., Sliter, M. T., \& Kirkendall, S. R. (2012). Analysis of a Rubric for Assessing Depth of Classroom Reflections. International Journal of ePortfolio, 2(1), 75-85. Retrieved from http://www.theijep.com/pdf/IJEP11.pdf

Garrett, N. (2011). An e-portfolio Design Supporting Ownership, Social Learning, and Ease of Use. Educational Technology and Society, 14(1), 187-202. Retrieved from http://www.ifets. info/journals/14_1/17.pdf

Hussey, J., \& Hussey, R. (1997). Business Research, a Practical Guide for Undergraduate and Postgraduate Students. London: MacMillan Business.

Jafari, A., Mcgee, P., \& Carmean, C. (2006). Managing Courses Defining Learning: What Faculty, Students, and Administrators Want. EDUCAUSE Review, 41(4), 50-70. Retrieved from http://net.educause.edu/ir/library/pdf/ERM0643.pdf

Merriam, S. B. (2001). Qualitative Research and Case Study Applications in Education (2nd ed.). San Francisco: Jossey-Bass Publishers.

Moon, J. A. (2006). Learning Journals, a Handbook for Reflective Practice and Professional Development (2nd ed.). Oxon: Routledge.

Plaisir, J. Y., Hachey, A. C., \& Theilheimer, R. (2011). Their Portfolios, Our Role: Examining a Community College Teacher Education Digital Portfolio Program from the Student's Perspective. Journal of Early Chidhood Teacher Education, 32(2), 159-175. doi: 10.1080/10901027.2011.572231

Van Maanen, J. (1983). Qualitative Methodology. London: Sage 